\title{
Measuring Gender, Development, and Land: Data-Driven Analysis and Land Reform in Lesotho ${ }^{1}$
}

\author{
Charles Fogelman \\ Department of Geography \& GIS \\ University of Illinois at Urbana-Champaign \\ 605 E Springfield Ave., Rm. 255 \\ Champaign, IL 61820 \\ Tel: $217-333-1880$ \\ Email: fogelma2@illinois.edu
}

\footnotetext{
${ }^{1}$ Support for this research was provided by the National Science Foundation (NSF award \#1333186), the University of Illinois Department of Geography and GIS, the University of Illinois Graduate College, and the University of Illinois Women and Gender in Global Perspectives Program
} 


\section{Measuring Gender, Development, and Land: Data-Driven Analysis and Land Reform in Lesotho}

\section{Introduction}

This paper focuses on a land reform in Lesotho, southern Africa, to explore theoretical concepts around development, land access, and measurement. The reform, which moved land allocation rights from traditional authorities to market exchange, was sponsored by the U.S. government's Millennium Challenge Corporation [MCC]. The MCC, a U.S. government agency separate from USAID and the State Department, is an international development agency dedicated to "poverty reduction through economic growth." The MCC has demonstrated that it acknowledges "the critical role that land, natural resources and other property assets play in economic development" (MCC.gov), with at least 15 of its funded projects devoting money to land rights. This is substantial, accounting for a third of MCC's 45 partner countries. Among MCC's main foci is "data-driven" development.

The MCC contributed $\$ 20$ million to Lesotho's land reform. That funding was contingent on the passage and execution of Land Act 2010 by Lesotho's Parliament. That law was part of a number of other pieces of legislation that sought to "modernize" (MCC Compact) Lesotho's land tenure system. The land tenure system that existed prior to these laws allowed chiefs substantial power in determining the allocation of land. The MCC and Government of Lesotho (GoL) prioritized passage of these laws, in part to remove a significant remaining power of the chieftaincy. This reflects a longstanding tension between institutions of the state in Lesotho and the chiefs. Of a similar effort at land reform in 1973, R.C. Leduka said "it brings into sharp relief the historically entrenched political and institutional tensions between customary and Lesotho's colonial and postcolonial states" (Leduka 2007, 104-5).

Women were a targeted demographic of this development intervention. Women's status in Lesotho is complex and changing. On one hand, a majority of primary school students in the country are girls, and the World Economic Forum regularly ranks Lesotho highly on its Global Gender Gap report. On the other, married women were legally considered minors until 2006. The shape of labor and geography is also changing in Lesotho. Before 2000, a massive number of working-age men traveled to South Africa to work in that country's mining sector. Since the end of Apartheid rule in South Africa, that country's labor market has shrunk significantly to 
Lesotho citizens. At the same time, favorable U.S. trade policy has made Lesotho a hotbed of textile production. Several American clothing companies produce clothing in Taiwanese and Chinese-owned factories that employ 40,000 people, nearly all of them women (Rosenberg 2007). Lesotho has a long history of gender politics vis-à-vis land access (Epprecht 2000, Eldredge 2007). In this paper, I explore the fortunes of women in one village in the context of a changing legal landscape. How has the altering of laws in Lesotho changed the land access of women in a peri-urban village and what does that say about the measurement techniques of the MCC and other development agencies? Further, what role has "data-driven" measurement had in determining access?

To answer these questions, I focus on a village on the margins of Maseru, Lesotho's capital. I draw on data from a village I call Ha Mohapi, to protect informants' anonymity. The data reveal a story of gender, land dispossession, and urbanization, all situated within the context of "development." In short, the MCC's too-brief measurement of land reform in Lesotho created a situation in which women received leases to land at a remarkable rate. However, that seeming progress was undone by the weak tenure security the leases provided. I argue that the MCC and GoL created a situation in which security of land tenure was more easily obtained by the wealthy than the poor whom the reform ostensibly targeted. The short-term focus of the MCC's data obscured these negative outcomes and portrayed their work as an unqualified success.

\section{Land, Gender, and Law in Lesotho}

Recent legislation in Lesotho attempts to maintain and improve women's status there by securing their rights to land in the face of threats, both real and perceived. Three laws, sponsored and supported by the U.S. government and other donor states and agencies, are geared at improving women's legal status in Lesotho. Local Government Act 1997 (which took effect in 2005) fully moves land allocation power from chiefs to elected committees. Legal Capacity of Married Persons Act 2006 bestows full citizenship and full property ownership rights on women, rather than subjugating them as minors to the will of husbands or fathers. In terms of land rights, the legislation culminated in passage of Land Act 2010, which has been a major force in moving women's land rights from customary authorities - unelected village chiefs - to the open market. The Act mandates that all landholders in urban areas obtain leasehold titles to land, rather than the customary allocation papers (commonly called "Form Cs") that had previously governed land 
rights. These leases are exchangeable and alienable, and they remove chiefs' power over land in urban areas.

Passage of Land Act 2010 came after a long series of conversations and contestations among Basotho politicians and people and external development agencies and scholars. Early drafts of the law were proposed in Parliament in 2001 and 2004, but neither passed. The 2010 debate over the law that eventually did pass was contentious enough that the opposition walked out of Parliament, citing pressure from the U.S. to "bulldoze" the law through the assembly with a minimum of public consultation (Zihlangu 2010). Leaked diplomatic cables from the U.S. Embassy in Maseru reveal that there was little will in the ruling party to pass the law. Those cables indicate that it was largely that the U.S. made the $\$ 20 \mathrm{~mm}$ of the MCC/Lesotho compact earmarked for land reform contingent on Land Act 2010's passage (Wikileaks 2009, 2010).

An important reason given by both the MCC and the Lesotho government for the legal changes to the land regime in Lesotho was to extend more equitable and less capricious land rights to women than existed previously (Sekatle 2009). Before 2006, Basotho women were typically minors in the eyes of the law: "[B]efore marriage, women were children of their fathers, after marriage they were children of their husbands, and during their widowhood they were children of their heirs or sons" (Molapo, 1994, cited in Kalabamu 2006, 237). In this reality, women were effectively second class citizens. An earlier law, the Legal Capacity of Married Persons Act 2006 bestowed full citizenship and full property ownership rights on women, rather than subjugating them to the will of husbands or fathers. Land Act 2010 worked to bring Lesotho's land law into harmony with that law, as well as ensuring full inheritance rights for widows. Now that Land Act 2010 has afforded more equitable rights to women, the argument backing these legal innovations suggests that women's status in Lesotho has been further strengthened and sustained.

A second objective of the legal reforms related to the chieftaincy. Supporters of the Land Act 2010 invoked a variety of reasons for the law, including economic efficiency. The chieftaincy was also routinely invoked by supporters, with a representative report calling into question chiefs' representativeness and accountability, and accusing their power of lacking "clear and consistent principles of participation, transparency and accountability" (Adams and Turner 2005). Chiefs' power, which had steadily diminished since independence, was by 1979 largely based on land allocation rights. The entrepreneurial spirit of chiefs helped keep Land Act 1979 
from being executed. Their widespread backdating of Form Cs to read 1978, even those they issued decades after 1978 (Leduka 2006, Leduka and Setsabi 2008), effectively undermined the 1979 law. The backdating of Form Cs was well-known and one of the main shortcomings of the pre-2010 land tenure system in Lesotho identified by outsiders (UN-HABITAT 2006).

Agarwal argues that women's ownership of land leads directly to improved social, economic and political outcomes for women (Agarwal 2001). But there is a distinction between the "bundle of rights" that has been afforded to women in places like Lesotho and the "bundle of powers" that allow women to benefit from these rights (Ribot and Peluso 2003); those powers are what will determine whether women truly benefit socially, economically and politically from land reforms. Leslie Gray and Michael Kevane wrote over a decade ago that "the trend is clear throughout the continent: women's rights to use land, gained through husbands or kin, are exposed as secondary and diminishing" (Gray and Kevane 1999, 33) Their research, however, pointed to ways that women were subverting their secondary and diminishing place. "These actions have enabled women to create new routes of access to land, and in some cases, new rights" (Gray and Kevane 1999, 33). It is these "new routes" and "new rights," along with "new abilities," that Lesotho's recent land reform claims to encourage, in the form of market-led land rights. The main benefits that were expected to accrue to women from Land Act 2010 were the ability to control surpluses (from production on or sale of land), the ability to obtain credit with their land as collateral, and the freedom from dispossession by in-laws after a husband's death.

\section{The Role of Data in Development}

The MCC is a proudly data-driven organization. One of the organization's founding principles states: "data-driven analytical rigor and a focus on outcomes should govern resource allocation, project design, and results measurement" (mcc.gov). Sub-Saharan Africa often lacks robust data sets. However, this lack has not limited the conclusions that scholars have drawn from these data. Morten Jerven has, in two recent books $(2013,2015)$ demonstrated that Western development economists frequently use statistical models to fill the data gap. However, the data they use as input variables are notoriously unreliable, making the modeled results just as unreliable. Another scholar was less charitable in this regard, contending that "[m]uch of African econometrics is simply a vast exercise in garbage in, garbage out" (de Waal 2016). 
Similarly, data about women's land rights and land access are notoriously unreliable (Doss, et al. 2015). A team of agricultural economists say that the evidence is getting stronger, but remains incomplete:

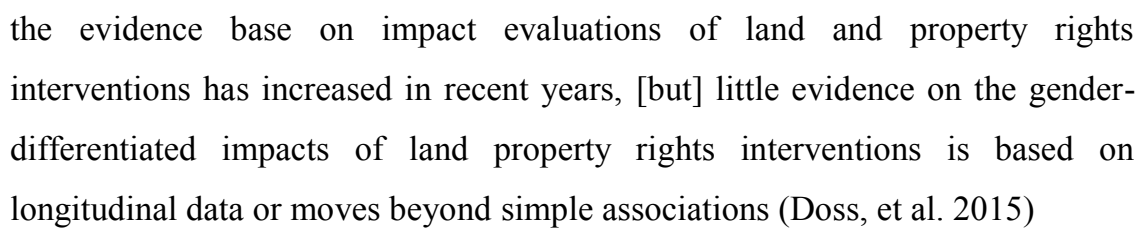

That increasing evidence base is a good thing, but there is a very real concern that the evidence collected on this topic privileges "new rights" ahead of "new abilities." I will explore this distinction in further detail below.

The metrics of poverty and development in sub-Saharan Africa are limited, and must often be gathered (or modeled) by agencies. The ways these phenomena are measured is built on "fundamental assumptions as to [poverty's] nature and causes" (Lok-Dessallien 1999, 10), but those assumptions are then built in to the measurements, as the intensely political and contested assumptions are depoliticized and "rendered technical" (Li 2005). In broad terms, these "fundamental assumptions" ask who or what is ultimately responsible for an individual's poverty. For example, making measures of credit access a focal point of a poverty reduction initiative makes the implicit assumption that limited exposure to markets is a main cause of poverty.

The measurement and rendering technical of a development intervention's outcomes can be a way of reinforcing the value and necessity of development interventions. As David Mosse phrased it, "development projects work to maintain themselves as coherent policy ideas (as systems of representations) as well as operational systems" (Mosse 2005, 17). Mosse argued that how a development intervention is monitored and evaluated is as important to its outcomes as what it is measuring. To these, I add a third, which goes largely unmentioned by Mosse: when the measurement of a development intervention happens and success or failure is declared, is as vital and important as how and what to the projects of poverty alleviation and to maintaining those projects as "coherent policy ideas" and "operational systems." (Mosse 2005).

\section{Access \& Vulnerability}

At its heart, the land reform in Lesotho is about land access. The MCC called joint titling for married people "an important step forward for gender equality and economic development" (MCC 2012). They further contended that an important element missing under the customary 
tenure regime was the ability for landholders to benefit from mortgage credit, because insecure tenure precluded them from borrowing against their land (MCC 2012). Access has been defined as "the ability to benefit from something," in this case the ability to benefit from land and land rights. In this, I follow Ribot and Peluso (2003), who draw a distinction between rights and abilities. In short, just because a law is on the books and targeted at a certain population means little, without the proper execution and enforcement of that law. Simply having legal right to a parcel of land in no way ensures one the ability to benefit from that parcel. Further access is needed to be able to benefit from that land: access to markets, to labor, to inputs, to capital, social relations, authority and technology, among others. This is what Ribot and Peluso call the "structural and relational mechanisms of access." Access does not happen in a vacuum; it is enhanced, governed and mediated by other actors, other accesses and other relationships.

Land access is never merely about the land - land is a place of many values: social, agricultural, economic, religious, and so on. Importantly, land is not merely a place of agriculture. Despite that, discussions among scholars and policymakers often see it as such. James Ferguson said that the tendency to conflate land and agriculture illustrates a troubling tendency, in all of these discussions, to reduce what we might call the land question (who has what rights to land, what do they do with it and with what implications) to the agrarian question (how farming is, or ought to be, organized, and with what role for peasants or other small agricultural producers) (Ferguson 2013, 166).

Access is important to Ferguson's point. To ask questions about access is to ask questions about people's ability to gain material benefits. As Ferguson makes clear, those benefits are not necessarily derived from agricultural uses of land. In fact, in the course of Lesotho's land reform, the MCC and the GoL rarely made any agricultural claims about the benefits that would flow to poor land holders. Instead, they focused on the benefits of "increased participation in the economy," in particular by a new ability for land holders to borrow money against a land lease. These material benefits were aimed at mitigating vulnerability. In the case of the MCC, that organization explicitly says that its goal is to reduce poverty. The GoL expressed a goal to "turn all land in Lesotho into an economic asset with the ultimate aim of changing the lives of all Basotho for the better" (Sekatle 2009).

Since at least 1970, the Lesotho state has focused heavily on large scale development projects (Aerni-Flessner 2014) The recent history of these large projects illustrates that HIV- 
oriented projects have appropriated "the language of participation, decentralization and community partnership" (Kenworthy 2014, 39), but have routinely demonstrated disdain for those concepts when practiced by Basotho. Another troubling finding investigated women's land access in Lesotho, before the passage of Land Act 2010. Braun (2010) investigated a compensation program for households affected by a major dam project. Her work found that the women's land rights were diminished by both the dam project and by the compensation project that followed it. Her research found that "devaluing of women's labour on the farms and in the households served to exclude them from being legitimate receivers of 'development', reproducing male ownership and patriarchal authority with significant implications for food security" (Braun 2010, 463). However, Braun's research, conducted from 1997 to 2002, predates Lesotho's recent legal innovations. Her findings about women's inability to legitimately receive 'development' are what government legislation and the MCC sought to remedy with their own development projects. MCC showed how this would work: those who received a lease were the occupants of land, and "the occupants will become the proprietors of an asset whose value is expected to appreciate substantially with formalization, and will have new incentives to invest in their homes" (MCC 2012, 5).

\section{Whose Land? Land Reform in Lesotho}

The macro-level news from Lesotho appears to be encouraging. Figure 1, which shows the gender distribution of household leases ${ }^{1}$ before and after the institution of Land Act 2010 suggests a rousing success. Before the Act was instituted, only a handful of leases (4\%) were jointly allocated. A large majority (73\%) were held by men alone and under a quarter $(23 \%)$ were female-held. Since the Act started governing land tenure in urban and peri-urban Lesotho, there has been a major shift in terms of land rights by sex. From the beginning of 2011, only $14 \%$ of new leases have gone to men, while $34 \%$ have gone to women, and $52 \%$ have been issued to married couples jointly ${ }^{2}$. The tide of women's rights to benefit from land in Lesotho has turned. This is not, however, to say that the ability to benefit from that land has also markedly changed.

\footnotetext{
${ }^{1}$ This count includes all leases that are registered by individuals or married couples, and not by churches, the state, companies, non-profits, and cooperatives. Those non-household leases total about one half of one percent of all leases issued in Lesotho.

${ }^{2}$ The seeming overrepresentation of women in receiving leases since Land Act 2010 raises questions that are beyond the purview of this paper, but worthy of further study.
} 


\section{[FIGURE 1 APPROXIMATELY HERE]}

Land Act 2010 is working the way it was intended to secure women's rights to land ownership. Many times more plots of land are under leasehold now than before the law, and a majority of new leases have women's names on them (either as sole leaseholders or equal partners with their husbands). The law's objectives fell under the vague MCC heading of "increasing the participation of women in the economy" in the Compact between the MCC and Lesotho's government. More specifically, there were three objectives of the Act that are central to this paper. First, the Land Act co-operated the Legal Capacity of Married Persons Act to ensure that women could hold leases and inherit leases when they were the next-of-kin of a deceased leaseholder. Second and relatedly, those same two acts worked together to mandate that married couples both appear on leases, rather than just the husband ${ }^{3}$ as was the case before the Land Act. The third objective was spelled out by Pontšo Sekatle, the cabinet minister under whose portfolio the Land Act falls. In her presentation at the World Bank shortly before passage of the Act, Sekatle said that

The proposed Act will be a critical tool and help us turn all land in Lesotho into an economic asset with the ultimate aim of changing the lives of all Basotho for the better. The lengthy nationwide consultative process has confirmed that security of tenure issue will encourage both national and foreign investors to develop their properties and use them as economic assets (Sekatle 2009).

She then closed her presentation with an assertion about what she called the foremost objective of the Act, poverty reduction for the vulnerable. "Most importantly we believe that land registration and gender-balanced inheritance in land ownership will go a long way to secure the rights of poor and vulnerable groups" (Sekatle 2009). Sekatle's goals were shared with the MCC (MCC Compact). This paper investigates Sekatle's assertions. First, how far did the reform go to securing the rights of the poor and vulnerable, particularly women? Second, did the rights of the poor and vulnerable genuinely trump those of "national and foreign investors"? Finally, and critically, I examine answers to these questions through a broader temporal lens. One's ability to benefit from land in peri-urban Maseru in 2012 does not imply that one has the same ability in 2016. In fact, the tools that could confer land access on the "poor and vulnerable" in 2012 may

\footnotetext{
${ }^{3}$ Unlike in South Africa, Lesotho's only neighbor, same-sex marriage is not recognized in Lesotho as of 2015.
} 
be the same tools used to limit or remove their access to that land in 2016. Those tools could then shift the ability to benefit from that land to "national and foreign investors." This is precisely what I will argue has happened in Ha Mohapi, a village in peri-urban Maseru. I argue that measurements of access, particularly those routinely used by international development agencies, are too short-sighted to capture the constantly shifting "structural and relational mechanisms" (Ribot and Peluso 2003) of access.

\section{The Gendered Outcomes of Reform in a Peri-Urban Village}

The news from Ha Mohapi, an urbanizing village on the margins of Maseru's urban area, appears just as positive as the news from elsewhere in Lesotho. Ha Mohapi is technically within Maseru City, and it is thus subject to mandated leases for all parcels of land. The gender balance of lease allocation there mirrors the rest of the country. Of the leases that have been registered to households in Ha Mohapi (only one lease there predates 2010), 52\% of them are jointly registered, $31 \%$ to women alone and $17 \%$ to men alone. According to the aggregate scale at which development agencies measure gender equity, Ha Mohapi is a success story.

My own field-based research in Ha Mohapi served to reinforce much of this success story. I interviewed the village chief, the area chief, government bureaucrats and development agency officials in 2012, 2013, and 2014. I chose Ha Mohapi as my research site for two reasons. First, as of 2012, it was one of four villages within the Maseru urban area with over $25 \%$ of its land area devoted to agricultural fields. Less interesting, but no less important, it was the only one of those villages where the local chief would allow me access to his village. I also conducted in-depth (60-120 minute) interviews with men and women in 41 households within Ha Mohapi to investigate three main areas that can illuminate the gendered nature of land rights and land powers in Ha Mohapi. These three areas I identified from previous research to be most likely threatened in Lesotho: intra-household decision making about land, treatment by local authorities, and attempts at land dispossession (Drimie 2003, Mutangadura 2004, Eldredge 1991, Kalabamu 2006, Mphale, et al. 2002, Epprecht 2000, UN-HABITAT 2006, Sekatle 2009). 
Questions on intra-household decision-making ${ }^{4}$ demonstrated that husbands make more decisions about land than their wives, but that household harmony was more important to most women than equitable decision-making. Questions about representation and treatment by local authorities indicated that neither the elected councilor nor the local chief was an important force in most Ha Mohapi residents' lives. It was another matter - that of dispossession - that complicated, and perhaps even contradicted, the optimism implicit in Figure 1.

A phenomenon that land titling advocates say is ameliorated by titling, but critics say is only exacerbated, is land dispossession. On the question of attempts to dispossess people of their land in Ha Mohapi, the results are ambiguous. An important gender dimension of the Land Act 2010 was to strengthen inheritance rights for widows. The Land Act 2010 harmonized Lesotho's land laws with the Legal Capacity of Married Persons Act 2006, which made married women full citizens under Lesotho's laws, as opposed to minors under their husbands' dominion. Inheritance conflicts were common before passage of the Land Act 2010, and a large number were resolved at the expense of widows in favor of relatives who were not next-of-kin (Mphale 2002). Limited evidence from Ha Mohapi, of three women who were recently widowed compared to four who were widowed before Land Act 2010, indicates that inheritance of land is better-protected now. None of the women whose husbands had died since 2011 expressed concern that her land would be taken by her husband's family. They each attributed this security, in part, to the legal standing of their leases.

The problem of land inheritance bypassing the widows to whom it should go has not fully been solved by Land Act 2010. It has, however, been greatly improved; the once-pervasive problem of land not passing to widows is no longer in evidence in Ha Mohapi. On this, the tenure security provided by legal reform has been instrumental in ensuring both women's right and ability to benefit from their land.

The ongoing threat to land access in Ha Mohapi appears to be not from a widow's opportunistic in-laws. Instead, the people of the village are under threat from a far different source: real estate capital, with assistance from the state. Every hectare of what had been $\mathrm{Ha}$ Mohapi's agricultural land has been sold since 2011, with most sales completed in 2013 or 2014. These purchases were at prices well below what any informant households thought was a fair

\footnotetext{
${ }^{4}$ The interviews were semi-structured, so follow-up questions varied, but I asked husbands and wives separately who made decisions in their household about 1 . What crops to grow, 2 . What crops to sell and what to eat/use, 3 . What to do with any money raised from sale of crops, 4 . Who would decide to sell the land if they chose to do so.
} 
price. Although the land market in Maseru is a nascent one and it is difficult to determine consistent pricing (Leduka 2012), most of the informants with whom I spoke believed that the land would have sold on the open market for about three times the price they received. These informants used their fields for either consumption or sale, and even those who did want to participate in a land market were compelled to participate in a weighted and unequal one. Residents were approached by investment companies to negotiate the sale of their land. Soon it became clear that the transactions were not strictly willing buyer-willing seller sales. When asked why they entered into an agreement for a price that was too low, each household said that they felt a great deal of pressure to sell from representatives of the Maseru Municipal government, and those residents were warned that compensation for the land sales would arrive slowly for those who did not take the offered rate, or that they might be expropriated without compensation $^{5}$. The pressure from the Municipal government illustrates an anti-democratic element of the reform. While the Land Act 2010 and associated other legislation were supposed to disempower chiefs while passing those powers to elected officials, my own research indicated that the elected officials are largely ceremonial, and vote as (unelected) Municipality bureaucrats encourage them to vote. The area that Ha Mohapi's residents have sold is planned to be a golf course and housing development. In short, the state and investment capital appear to have conspired to threaten dispossession and keep sale prices low in order to hasten the passage of leaseholds from smallholders to developers. The people who have sold their fields are at a loss. With no land outside of their family homesteads, few expect (or even want) to stay in Ha Mohapi for much longer. Most expressed a resignation that their days in Ha Mohapi were numbered; soon, they told me, it would be a village for the wealthy. One informant, however, expressed an even starker resignation. When I asked her if she expected to one day leave the village, she said "And go where? There is nowhere we can go; we will stay until we die."

\section{Discussion}

On September 17, 2013, the MCC Compact in Lesotho ended. The MCC handed over its remaining projects to the Lesotho government. Much of the \$358 million spent on MCC-style

\footnotetext{
${ }^{5}$ Land Act 2010 sets a very low standard for expropriation by eminent domain, as defined by sections 49, 50, 51, and 52 of the Act. The Minister of Local Government has absolute power to declare what land is to expropriated and what compensation (if any) will be paid for the land.
} 
development in Lesotho went largely to important infrastructure improvements. The land reform element of the MCC's work only accounted for about 7\% of the total MCC Compact funds.

Despite the relatively low cost, land reform may be one of the most far reaching elements of the Compact, because it has fundamentally altered the social relations governing land access, and the myriad uses and meanings that can be attached it it. The land reform has altered chiefly authority (as well as bureaucrats' and elected officials' authority) and the relationships between gender and land in Lesotho. The reverberations of these changes will be felt for many years to come.

Those many years form the crux of my main argument here. Land access is not necessarily transferrable or sustainable over time. Having power over land today makes it more likely that one will have it tomorrow, but it is not reasonable to assume that such power will persist indefinitely, especially when (as in the case of Lesotho), the land tenure regime is rapidly changing. The MCC's methods of short-term measurement are antithetical to this understanding; MCC departed Lesotho in 2013 and declared its programs successes or failures then. The way Land Act 2010 was lived in September 2013, at least in Ha Mohapi, was much different from how it looked only a few months later. Leases passed to women in remarkable numbers, but that alone is not illustrative of substantive change in the bundle of powers that allow women to gain material benefits from the land. Those lease numbers demonstrate that the right to benefit from their land had passed to a huge number of women, but it said little of the ability to benefit. In fact, just as MCC was departing Lesotho, well-capitalized real estate developers, with assistance from the state, were beginning a process that amounted to dispossession. Those they dispossessed were disproportionately women, as a substantial majority of leases in Ha Mohapi (and Lesotho in general) have been issued to women, either alone or with their husbands. This points to an issue with the metrics of development; the success of a project today and the success of a project tomorrow are not necessarily related. In fact, when social relations are substantially altered by a project, as they were in Lesotho, the mechanisms of the success of a project today may even be its undoing tomorrow. Women in Lesotho received leases, and the potentially secure tenure that leases provide, in remarkable numbers. However, the ability to benefit from secure tenure relies on state institutions using eminent domain laws judiciously and not interfering by pressuring landholders to sell. In Ha Mohapi, this did not happen. As a result, those with the true ability to benefit from land were not the women who received leases. 
The story of women's land access in Ha Mohapi is not meant to serve as an indictment of the MCC's projects in Lesotho, nor of the Lesotho Government's substantial land reform project. Instead, it serves as an illustration of two important things. First, the land tenure security of vulnerable people, particularly women, is very easily threatened, even when it appears that bulwarks are in place. Especially when land rights have recently been clarified and marketized, it is not a surprise to see investors taking advantage of a nascent market in land. Considering the assistance those investors had from the state in keeping land prices low in Ha Mohapi, it is logical to assume that smallholder land tenure security would be threatened. Given that women were largely the initial beneficiaries of land titling, it is not entirely shocking that their land access is showing signs of being tenuous.

This leads to the second point illustrated by Ha Mohapi. Women's ability to obtain the structural and relational mechanisms of access are more likely to be precarious than men. Women have, according to most measurements, lower social status than men in every country around the world (World Economic Forum 2015, UNDP 2015). The mechanisms of access are constantly shifting, and, especially in a landscape of rapid change where new rights and powers are being afforded to vulnerable people, access cannot be measured at just one point in time. In the case of Ha Mohapi, it appears that women's vulnerability has increased. The land from which they were supposed to benefit is no longer theirs, and the sale price was apparently a fraction of its fair market value. Their increased vulnerability has not been captured in the MCC's data. Instead, in the eyes of the MCC, the story of poor and vulnerable people has been a positive one, and one that effectively ended in September of 2013.

MCC's declaration of project success on September 17, 2013, is reflective of an overly short-term focus by development agencies. Rather than working with a 10-year, 20-year, or longer time horizon, agencies pay lip service to those time horizons, but rarely collect, publish, or learn from meaningful data on that scale. The time has come for development agencies to account for the years after their projects end. This is consistent with Jerven $(2013,2015)$ and de Waal's (2016) appeals for true "evidence-based policy" (Jerven 2015). In the case of Ha Mohapi, heeding this call would have illustrated the limitations of Land Act 2010 to ameliorate the vulnerabilities the MCC and GoL targeted through the reform. The effective circumventing of democracy by bureaucrats and the dispossession of women, the poor, and the vulnerable (the exact three groups Minister Sekatle said the land reform was supposed to assist) were largely 
invisible to the MCC. This is because, though they profess to be governed by analytical rigor, the data are too limited. The outcomes are consistent with claims that mobilizing limited data can do more harm than good (de Waal 2016). In Lesotho, these data limitations have had a material outcome. Land reform in Ha Mohapi, and the rest of Maseru, has been declared a success by the MCC. This declaration of success based on limited data masks the reality. Vulnerability to hunger and deepening poverty appeared to have been mitigated when MCC left Lesotho and declared success. The limited scope of the data that allowed for the MCC to claim a successful outcome helped to obscure the processes ongoing in Ha Mohapi. The micro-level data discussed in this article indicate that an unequivocal declaration of success is, at best, an incomplete picture of women's land access in Maseru.

The measurement performed by the MCC served as much to justify further MCC interventions as to determine policy success. Even the organization's own claims about its relative success were questioned by the architects of a planned second MCC-Lesotho Compact, who identified "poor land management allocation systems" as a "binding constraint" (LMDA 2014) to development in Lesotho in 2014, once again claiming that ineffective allocation and gender inequality were abiding issues. Perhaps not coincidentally, several of the same MCC consultants who were intimately involved with Land Act 2010's passage are among the contributing authors on this report.

\section{Conclusion}

In this paper, I have argued that the MCC, Land Act 2010 and the other contributors to Lesotho's land reform have failed in their stated goal of limiting the vulnerability of women and the poor. This is nothing new: James Ferguson illustrated that "[f]or the 'development' industry in Lesotho, 'failure' appears to be the norm" (Ferguson 1990, 8), while illustrating how the logics and processes of development often proved more powerful than those of the state or the public. Despite laws, development programs and data analysis aimed at changing both women's rights and powers to benefit from land in Lesotho, the outcomes of Land Act 2010 show little evidence of having increased women's tenure security. In fact, there is ample evidence from Ha Mohapi that women's tenure security has worsened. This is in spite of (and because of) the data and measurement focus of the MCC. The MCC's activity in Lesotho and the GoL's legislation both espoused a focus on mitigating the vulnerability of women and the poor. However, the outcomes 
of this research suggest that little has changed since Braun's research in 2003, when she said of her project:

"The research also suggests that gender must be central to the constitution and implementation of large-scale development projects' mitigation policies if they are to contribute to food security, rather than exacerbate it, and if they are to serve the broader goals of reducing poverty, promoting equity, and supporting women's rights within their households and within societies" (Braun 2010, 462).

A development project and series of reforms did little to mitigate women's vulnerability in terms of landholding in Lesotho. It appears that the reforms are not enough, in themselves, to forestall challenges to women's landholding. However, the measurement of the MCC demonstrated the opposite. The "broader goals" of poverty reduction and gender equity appeared achieved in 2013, but further investigation shows that, at least in Ha Mohapi, the achievement was merely a temporary data point on the way to outcomes that turn that narrative on its head. Whether Ha Mohapi is unique in this regard remains to be seen. Further research on the outcomes of Land Act 2010 in Lesotho is needed to help illuminate its role. Has Ha Mohapi faced a perfect storm that led to far different outcomes than the MCC claimed? Or has the Act made outcomes like that of Ha Mohapi more prevalent throughout Lesotho? This study demonstrates that the possibility of dispossession has been created by a development project in Lesotho; additional work would determine the pervasiveness of dispossessions like this one. Similarly, there is a need additional research that explores the MCC's land projects elsewhere. Have projects elsewhere produced outcomes like that of Ha Mohapi?

\section{Acknowledgements}

The author wishes to acknowledge funding support from the National Science Foundation (NSF Award \#1333186), and the University of Illinois Department of Geography and GIS, Graduate College, Women \& Gender in Global Perspectives Program, and Cultures of Law in Global Contexts Project. The author is grateful for the support, assistance and helpful feedback of Tom Bassett, Liteboho Tšoako, and three anonymous reviewers, all of whom have strengthened this paper. Any errors or absences are the fault of the author.

\section{Works Cited}


Adams, Martin, and Stephen Turner. 2005. Integrating Land Tenure Issues Into Lesotho's Food Security Policy. Vol. 3. Kingdom of Lesotho.

Aerni-Flessner, John. 2014. "Development, Politics, And The Centralization Of State Power In Lesotho, 1960-75." The Journal of African History 55 (3): 401-421.

Agarwal, Bina. 2001. "Participatory Exclusions, Community Forestry, and Gender: An Analysis for South Asia and a Conceptual Framework." World Development 29 (10): 1623-1648.

Braun, Yvonne A. 2010. "Gender, Large-Scale Development, and Food Insecurity in Lesotho: An Analysis of the Impact of the Lesotho Highlands Water Project." Gender \& Development 18 (3): 453-64. doi:10.1080/13552074.2010.522028.

de Waal, A. 2016. "Next Generation Social Sciences » Alex de Waal." SSRC.org. http://nextgen.ssrc.org/fellows/spotlight/towards-a-social-science-in-africa-fit-for-purpose/.

Doss, Cheryl R., Chiara Kovarik, Amber Peterman, Agnes R. Quisumbing, and Mara Van den Bold. 2013. "Gender Inequalities in Ownership and Control of Land in Africa: Myths versus Reality." http://papers.ssrn.com/sol3/papers.cfm?abstract_id=2373241.

Drimie, S. 2003. "HIV/AIDS and Land: Case Studies from Kenya, Lesotho and South Africa." Development Southern Africa 20 (5): 647-658.

Eldredge, Elizabeth. 1991. "Women in Production: The Economic Role of Women in Nineteenth-Century Lesotho." Signs 16 (4): 707-731. . 2007. Power in Colonial Africa: Conflict and Discourse in Lesotho, 1870-1960. Univ of Wisconsin Press.

Epprecht, Marc. 2000. "This Matter of Women Is Getting Very Bad": Gender, Development and Politics in Colonial Lesotho. University of Natal Press.

Ferguson, James. 1990. The Anti-Politics Machine: “development," Depoliticization, and Bureaucratic Power in Lesotho. U of Minnesota Press.

—. 2013. "How to Do Things with Land: A Distributive Perspective on Rural Livelihoods in Southern Africa." Journal of Agrarian Change 13 (1): 166-74. doi:10.1111/j.1471-0366.2012.00363.x.

- 2015. Give a Man a Fish: Reflections on the New Politics of Distribution. Duke University Press.

Gray, Leslie, and Michael Kevane. 1999. "Diminished Access, Diverted Exclusion: Women and Land Tenure in Sub-Saharan Africa." African Studies Review 42 (2): 15-39.

Jerven, Morten. 2013. Poor Numbers: How We Are Misled by African Development Statistics and What to Do about It. Cornell University Press.

. 2015. Africa: Why Economists Get It Wrong. Zed Books.

Kalabamu, F. 2006. "Patriarchy and Women's Land Rights in Botswana." Land Use Policy 23 (3): 237-46. doi:http://dx.doi.org/10.1016/j.landusepol.2004.11.001.

Kenworthy, Nora J. 2014. "Participation, Decentralisation and Déjà vu: Remaking Democracy in Response to AIDS?" Global Public Health 9 (1-2): 25-42.

Leduka, R. C. 2007. "Recycled Fable or Immutable Truth? Reflections on the 1973 Land-Tenure Reform Project in Lesotho and Lessons for the Future." Africa Today 53 (3): 91-111.

_. 2012. "Lesotho Urban Land Market Scoping Study." Report for Urban LandMark, ISAS, Roma, 2.

Leduka, Resetselemang C. 2004. Informal Land Delivery Processes and Access to Land for the Poor in Maseru, Lesotho. International Development Department, School of Public Policy, University of Birmingham.

Leduka, Resetselemang Clement, and Setšabi Setšabi. 2008. “The Two Facets of Lesotho's Urban Land Law and Implications for Planning." Urban Forum 19 (February): 23-41. doi:10.1007/s12132-008-9023-z.

Li, Tania Murray. 2007. The Will to Improve: Governmentality, Development, and the Practice of Politics. Duke University Press.

Lok-Dessallien, Renata. 1999. "Review of Poverty Concepts and Indicators." UNDP Soc Dev Poverty Elimin Div Poverty Reduct Ser from Http://www. Undp. orgpovertypublicationspovReview Pdf 21. http://down.cenet.org.cn/upfile/51/2011519172610196.pdf.

Molapo, M. 1994. "Women and Shelter Development." presented at the Housing for the Urban Poor Symposium, Birmingham, April 11.

Mosse, David. 2005. Cultivating Development: An Ethnography of Aid Policy and Practice. Pluto Press.

Mphale, M. M. 2002. "HIV/AIDS and Food Insecurity in Lesotho." Southern African Regional Poverty Network. http://www.sarpn.org/documents/d0000222/mphale/Lesotho_food_security.pdf.

Mutangadura, G. 2004. "Women and Land Tenure Rights in Southern Africa: A Human Rights-Based Approach." In Presentation at Land in Africa: Market Asset or Secure Livelihood Conference, London, UK, November, 8 9.

Ribot, J. C, and N. L Peluso. 2003. “A Theory of Access.” Rural Sociology 68 (2): 153-181. 
Rosenberg, Scott. 2007. "South African and Global Apartheid: The Experience of Basotho Labor in the South African Gold Mines and Taiwanese-Owned Textile Factories." Safundi 8 (4): 459-72. doi:10.1080/17533170701635378.

Sekatle, Pontso. 2009. "Securing Land Rights for the Poor and Marginalized in Lesotho." Paper Presented at the World Bank Annual Conference on Land Policy and Land Administration.

UN-HABITAT. 2006. Land Tenure, Housing Rights and Gender in Lesotho. UN-HABITAT.

Zihlangu, B. 2010. "MPs Walk out over Land Bill | Sunday Express." Lesotho Times. March 6. http://sundayexpress.co.ls/mps-walk-out-over-land-bill/. 
Figure

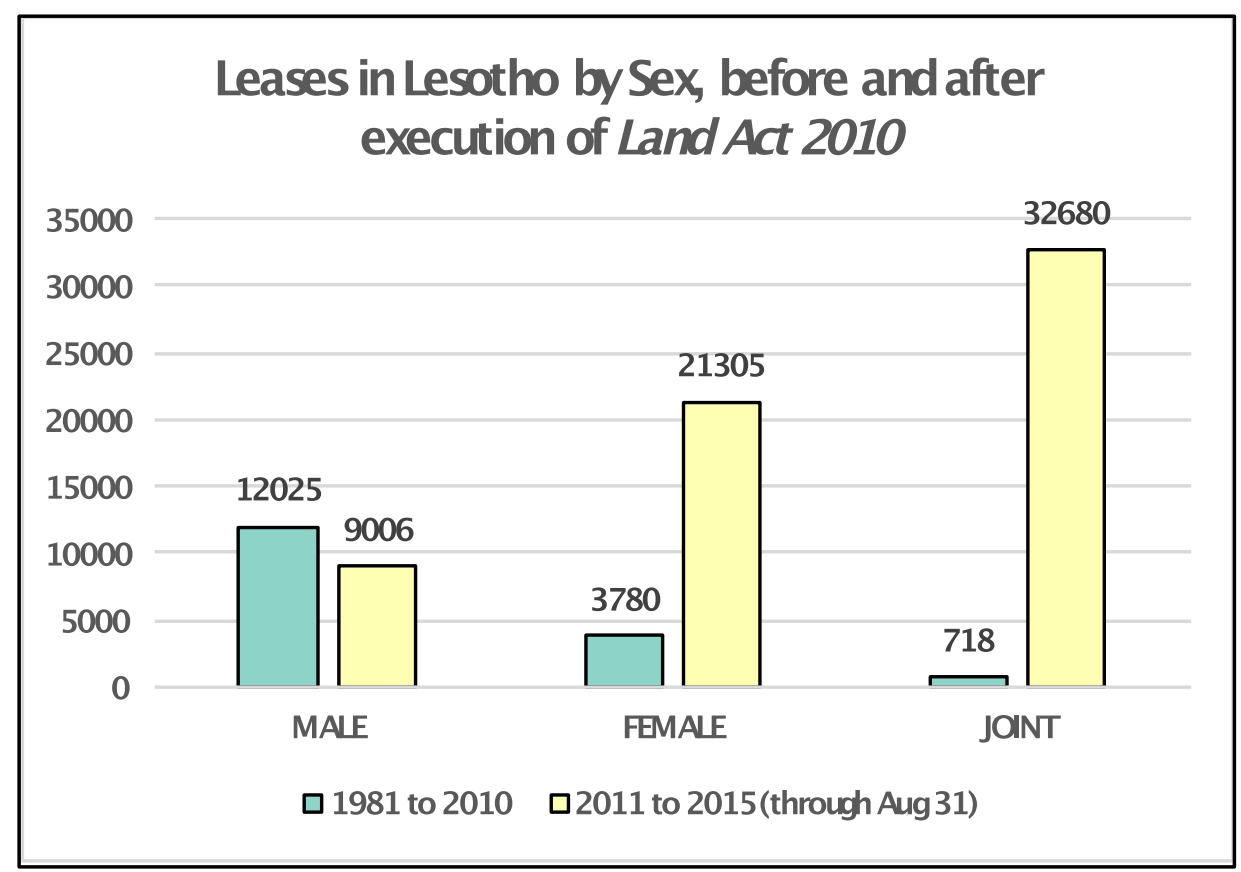

Figure 1: Total leases issued before and after the reform project (through August 2015) 